\title{
Occupational Exposure to Chemotherapy of Pharmacy Personnel at a Single Centre
}

\author{
Raveena Ramphal, Tejinder Bains, Geneviève Goulet, and Régis Vaillancourt
}

\begin{abstract}
Background: Cyclophosphamide is one of the most commonly used chemotherapy drugs worldwide. Data concerning environmental contamination and biological exposure of pharmacy personnel to this and other chemotherapy drugs are limited.
\end{abstract}

Objectives: To determine whether pharmacy personnel involved in preparing and checking cyclophosphamide doses were more likely to have detectable levels of this drug in their urine than non-oncology pharmacy personnel with no known contact with the drug, and to compare the degree of surface contamination with cyclophosphamide, methotrexate, and ifosfamide in the oncology pharmacy of a tertiary care pediatric hospital, where chemotherapy doses were prepared, and the main (control) pharmacy in the same institution, where no chemotherapy was prepared.

Methods: Biological exposure to cyclophosphamide was compared between pharmacy personnel who did and did not handle this drug by determining whether participants had detectable amounts of cyclophosphamide in their urine. Environmental exposure to chemotherapy drugs was assessed by using surface wipes to determine the degree of surface contamination with various chemotherapy agents in the oncology pharmacy and the main (control) pharmacy.

Results: On initial testing, cyclophosphamide was detected in the urine of all pharmacy personnel ( $n=7$ oncology personnel, $n=5$ control personnel). However, it was determined that all control personnel had been exposed to the oncology pharmacy on the day of testing. Repeat testing of these individuals revealed no positive samples among those not exposed to the oncology pharmacy on the day of repeat testing. The sole positive result on retesting of control personnel was for a participant who had been exposed to the oncology pharmacy on the retest day. Surface wipe testing revealed contamination of the oncology pharmacy with cyclophosphamide and methotrexate before and after cleaning, as well as contamination with ifosfamide after cleaning. The main (control) pharmacy showed no evidence of contamination with cyclophosphamide, methotrexate, or ifosfamide.

Conclusions: The findings suggest that environmental contamination plays a role in biological exposure to cyclophosphamide. Measures to reduce environmental contamination from chemotherapy and biological exposure of pharmacy personnel when handling chemotherapy agents should be identified and implemented as a priority.

Key Words: occupational exposure, chemotherapy, pharmacy, biological exposure, environmental exposure

\section{RÉSUMÉ}

Contexte : La cyclophosphamide est l'un des médicaments de chimiothérapie les plus couramment utilisés dans le monde. Or, il n'y a que très peu de données sur la contamination environnementale et l'exposition biologique du personnel de pharmacie à ces produits.

Objectifs : Déterminer si le personnel de pharmacie s'occupant de la préparation et de la vérification des doses de cyclophosphamide est plus susceptible de présenter des concentrations détectables de ce médicament dans leurs urines que le personnel de pharmacie ne travaillant pas en oncologie, donc sans contact connu avec ce médicament, et comparer le niveau de contamination de surface par la cyclophosphamide, le méthotrexate et l'ifosfamide dans la pharmacie d'oncologie d'un hôpital pédiatrique de soins tertiaires, où sont préparées les doses de chimiothérapie, à celui dans la pharmacie principale (témoin) du même établissement, où n'est préparée aucune chimiothérapie.

Méthodes : L'on a comparé l'exposition biologique à la cyclophosphamide du personnel de pharmacie ayant manipulé ce médicament à celle de personnel ne l'ayant pas manipulé en examinant si les participants présentaient des concentrations détectables de cyclophosphamide dans leurs urines. L'exposition environnementale aux produits de chimiothérapie a été évaluée à l'aide de lingettes utilisées pour essuyer les surfaces de la pharmacie d'oncologie et de la pharmacie principale (témoin) afin d'en déterminer les niveaux de contamination par différents agents de chimiothérapie.

Résultats : Lors de l'analyse initiale, des concentrations de cyclophosphamide ont été détectées dans les urines de l'ensemble du personnel de pharmacie ( $n=7$ dans l'équipe en oncologie et $n=5$ dans le groupe témoin). Mais l'on a constaté que tout le personnel du groupe témoin avait été exposé à la pharmacie d'oncologie le jour de l'analyse. Une seconde analyse chez ces personnes s'est montrée négative pour celles n'ayant pas été exposées à la pharmacie d'oncologie le jour de cette seconde analyse. Le seul résultat positif observé au cours de la seconde analyse chez le personnel du groupe témoin concernait un participant ayant été exposé à la pharmacie d'oncologie le jour de la seconde analyse. L'analyse des lingettes a révélé une contamination des surfaces de la pharmacie d'oncologie par la cyclophosphamide et le méthotrexate avant et après nettoyage ainsi qu'une contamination par l'ifosfamide après nettoyage. La pharmacie principale (témoin) ne présentait quant à elle aucun signe de contamination par l'un ou l'autre des trois produits.

Conclusions : D'après ces résultats, la contamination environnementale joue un rôle dans l'exposition biologique à la cyclophosphamide. Ainsi, trouver et mettre en place des mesures visant à réduire la contamination environnementale par les produits de chimiothérapie et l'exposition 
Can J Hosp Pharm. 2015;68(2):104-12 biologique du personnel de pharmacie lors de la manipulation de ces produits doit représenter une priorité.

Mots clés : exposition professionnelle, chimiothérapie, pharmacie, exposition biologique, exposition environnementale

\section{INTRODUCTION}

C yclophosphamide is one of the most commonly used chemotherapy drugs worldwide. It is a known carcinogen and is considered by the International Agency for Research on Cancer as a "non-threshold toxicant", which means that no safe lower threshold of dose can be assumed. ${ }^{1}$ It has also been associated with mutagenic, teratogenic, and reproductive effects. ${ }^{2-10}$ Pharmacists and pharmacy technicians handle this and other chemotherapy drugs in their most concentrated form over prolonged periods of time. The risk associated with this chronic, low-grade exposure has not been fully established.

Exposure can occur by absorption through skin, inhalation, or ingestion. Exposure can be measured biologically by looking for metabolites of cyclophosphamide in urine or environmentally by wiping surfaces with special surface wipes and analyzing the wipes.

Several studies, most done in Europe, have shown biological and environmental exposure of health care workers to cyclophosphamide and other chemotherapy agents. ${ }^{11-31}$ However, only a few studies in North America, most with small sample sizes, have concurrently investigated both environmental contamination and biological exposure to chemotherapy agents in health care workers, ${ }^{27,30,31}$ and none of these studies looked exclusively at pharmacy personnel. Only one of these studies, in which pharmacy personnel constituted a minority of participants, used a control group consisting of health care workers who did not handle chemotherapy agents. ${ }^{30}$ Several other studies have looked exclusively at environmental contamination in the North American setting. ${ }^{29,32-37}$

This study was undertaken to investigate the extent of biological exposure to cyclophosphamide among pharmacy personnel handling cyclophosphamide at a single Canadian institution and to compare exposure in this group with exposure in a control group of pharmacy personnel at the same institution who did not handle chemotherapy. In addition, the degree of surface contamination with chemotherapy agents in the oncology pharmacy (where chemotherapy doses were prepared) was compared before and after cleaning. Similarly, the degree of surface contamination in the oncology pharmacy was compared with that in the main (control) pharmacy, where no chemotherapy doses were prepared.

\section{METHODS}

\section{Study Design}

This cross-sectional practice study was conducted at a single pediatric hospital, the Children's Hospital of Eastern Ontario, in Ottawa, Ontario. The first aim was to determine whether personnel in the oncology pharmacy (who were involved in preparing and checking cyclophosphamide doses) were more likely to have detectable levels of cyclophosphamide in their urine than pharmacy personnel working in other areas (who had no known contact with cyclophosphamide). Each urine void from each participant was analyzed separately, with all analyses performed by a single laboratory (Exposure Control B.V., Wageningen, The Netherlands). If any urine sample for a particular participant had detectable amounts of cyclophosphamide (i.e., above the laboratory's lower limit of detection, $0.01 \mathrm{ng}$ cyclophosphamide per millilitre of urine), that participant was considered to have tested positive. The proportion of participants with detectable amounts of urinary cyclophosphamide was compared between the 2 arms of the study.

The second aim was to determine the degree of surface contamination with 3 chemotherapy drugs - cyclophosphamide, methotrexate, and ifosfamide - in the oncology pharmacy, where chemotherapy doses were prepared, and in the main (control) pharmacy, where no chemotherapy doses were prepared. Special surface wipes were used to sample prespecified areas in the oncology pharmacy without cleaning. Several months later, sampling in the oncology pharmacy was repeated, this time immediately after cleaning. Sampling was also conducted in the main pharmacy, where chemotherapy drugs were received and briefly stored but no chemotherapy doses were prepared; this area was considered as a control. The after-cleaning samples from the oncology pharmacy and the samples from the main pharmacy were obtained on the same day. Wipe samples obtained in the oncology pharmacy before cleaning were sent to the same laboratory as was used for testing urine samples (Exposure Control B.V.) for analysis of cyclophosphamide and methotrexate; after-cleaning samples were sent to this laboratory for analysis of cyclophosphamide only. In addition, after-cleaning samples obtained in the oncology pharmacy and control samples from the main pharmacy were sent to the toxicology laboratory of the 
Institut national de santé publique du Québec (INSPQ) in Québec, Quebec, for analysis of cyclophosphamide, methotrexate, and ifosfamide.

\section{Study Site}

The study was conducted from 2008 to 2009 at the Children's Hospital of Eastern Ontario, a Canadian pediatric hospital in Ottawa, Ontario. Each year about 140 patients receive chemotherapy at this hospital, and about 5200 doses of chemotherapy are administered.

The oncology pharmacy consisted of one open room. This room had office space, as well as a Class II Type B2 (total exhaust) biosafety cabinet, storage facilities for chemotherapy drugs, and a refrigerator. The biosafety cabinet was located at one end of the open room. Chemotherapy drugs were reconstituted and diluted within the biosafety cabinet. There was no separate negativepressure anteroom or negative-pressure hazardous clean room. The oncology pharmacy did not meet the standards for a Class 10000 clean room and did not have sufficient general exhaust ventilation (i.e., 20-30 air exchanges per hour for a clean room). Table 1 describes the hospital's oncology pharmacy in relation to standards set out in USP General Chapter $<797>.^{38}$ All chemotherapy drugs were stored in the oncology pharmacy. Chemotherapy doses were prepared by a specially trained pharmacy technician and verified by a chemotherapy pharmacist.

The main pharmacy, located on a different floor of the building, was where all drugs, including chemotherapy drugs, were received from suppliers. Chemotherapy drugs were briefly stored in the main pharmacy before being transported to the oncology pharmacy.

\section{Participants}

Individuals who were pharmacy personnel at the study institution were eligible to participate. Personnel from the oncology pharmacy handled cyclophosphamide on the day of study participation (i.e., 24-h urine collection), whereas none of the non-oncology pharmacy personnel handled cyclophosphamide on the day of study participation. The following potential participants were to be excluded: individuals who had themselves received chemotherapy in the past year, personnel who had already participated in the study, and non-oncology pharmacy personnel (controls) who had handled chemotherapy drugs in the week before study participation. All participants approached met the eligibility criteria, and therefore no one was

\section{Table 1. Description of Oncology Pharmacy in Relation to USP General Chapter $<797>$ Standards $^{38}$}

\section{Oncology Pharmacy at Study Institution}

\section{USP General Chapter <797> Standard}

Hazardous drugs shall be stored separately from other inventory, preferably within a containment area such as a negative-pressure room. The storage area should have sufficient general exhaust ventilation (12 air exchanges per hour).

Hazardous drugs shall be prepared in an ISO Class 5 environment with protective engineering controls in place and following aseptic practices.

\begin{tabular}{|c|c|c|}
\hline $\begin{array}{l}\text { Access shall be limited to areas were drugs are stored } \\
\text { and prepared. }\end{array}$ & No & $\begin{array}{l}\text { All staff had access to the oncology pharmacy during } \\
\text { working hours. }\end{array}$ \\
\hline $\begin{array}{l}\text { Hazardous drugs shall be prepared in a BSC that } \\
\text { meets the standards. }\end{array}$ & Yes & All injectable chemotherapy is made in a Class II BSC. \\
\hline $\begin{array}{l}\text { The ISO Class } 5 \text { BSC shall be placed in an ISO Class } 7 \\
\text { area that is physically separated and optimally has not } \\
\text { less than } 0.01 \text {-inch [0.025-cm] column negative- } \\
\text { pressure to adjacent positive-pressure ISO Class } 7 \text { or } \\
\text { better anteroom. A pressure indicator shall be installed } \\
\text { that can be readily monitored for correct room } \\
\text { pressurization. }\end{array}$ & No & $\begin{array}{l}\text { The BSC is located in an open space with no engineering } \\
\text { controls. }\end{array}$ \\
\hline $\begin{array}{l}\text { The BSC should be } 100 \% \text { vented to the outside air } \\
\text { through HEPA filtration. }\end{array}$ & Yes & \\
\hline $\begin{array}{l}\text { Appropriate PPE shall be worn when compounding in } \\
\text { the BSC and when using closed-system transfer devices. } \\
\text { PPE should include gowns, face masks, eye protection, } \\
\text { hair covers, shoe covers or dedicated shoes, and } \\
\text { double gloves. }\end{array}$ & $\begin{array}{c}\text { No } \\
\text { (partial) }\end{array}$ & $\begin{array}{l}\text { A closed-system transfer device was not used. While } \\
\text { compounding, pharmacy staff wore chemotherapy } \\
\text { gowns, face masks, hair covers, shoe covers, and } \\
\text { double gloves. } \\
\text { Chemotherapy drugs were prepared following standard } \\
\text { aseptic and negative-pressure technique. }\end{array}$ \\
\hline
\end{tabular}

BSC = biological safety cabinet, HEPA = high-efficiency particulate air, ISO = International Organization for Standardization, $\mathrm{PPE}=$ personal protective equipment. 
excluded from the study. All participants provided written informed consent to participate, and the study protocol was approved by the Research Ethics Board of the Children's Hospital of Eastern Ontario. Individual results were provided to each participant, with involvement of the Occupational Health Department. However, all of the samples were coded for privacy and blinded when sent for analysis.

\section{Data Collection}

All study participants completed a questionnaire that collected demographic data and asked questions about work practices on the day of study participation and questions related to the inclusion and exclusion criteria.

\section{Biological Measurement of Exposure to Cyclophosphamide}

Urine samples were collected from all participating pharmacy personnel over a 24-h period, starting midway through the shift. This allowed time for absorption and metabolism of the drug before excretion of active metabolites by the kidneys. The duration of sampling took into account the 3- to 12-h half-life of cyclophosphamide; as such, the 24-h collection period captured 2 to 8 half-lives of the drug. ${ }^{39}$ Repeat urine testing was required for the control group only (i.e., personnel not working with chemotherapy drugs), as it was discovered that during the initial urine collection period, this group had inadvertently been exposed to an environment that might have been contaminated (i.e., the oncology pharmacy).

Each participant used a specialized kit provided by the research laboratory that performed the analysis. Standardized written instructions accompanied the kit. Each kit consisted of a measuring cup to collect one entire void and 10 small tubes. From each void, a sample was drawn into one of the tubes with a suction device. The cup was then cleaned and used again for the next void. Samples collected during a work shift were stored in a designated hospital freezer at $-20^{\circ} \mathrm{C}$. The freezer was located in an office outside the oncology pharmacy, oncology ward, and oncology clinic. For samples collected at home, participants stored the samples in their home freezers and transferred the samples to the designated hospital freezer when they returned to work for their next shift. Samples were transported from home to hospital in cooler boxes with ice packs. All urine samples from each individual were placed together in a sealed plastic bag to prevent direct contact between urine tubes of different participants. The samples were batched and shipped on dry ice at $-80^{\circ} \mathrm{C}$ to the analysis laboratory in the Netherlands once a month for analysis. All samples were received in good condition.

Analysis of all urine samples was performed at the Exposure Control toxicology laboratory in the Netherlands. This laboratory specializes in biological and environmental monitoring of occupational exposure to antineoplastic agents in hospitals and the pharmaceutical industry. Analysis was done by gas chromatography-mass spectrometry, as described by Sessink and others. ${ }^{40}$ Most relevant studies published to date have used this laboratory for analysis, so the methods of both collection and analysis were standardized, making studies more comparable than if analyses had been performed by different laboratories. To the authors' knowledge, there is no commercial centre in North America that performs urine testing for cyclophosphamide.

\section{Environmental Measurement of Exposure to Cyclophosphamide}

To measure environmental contamination with cyclophosphamide and methotrexate without cleaning, surface wipe samples were collected from 6 specific areas in the oncology pharmacy. The samples were collected after chemotherapy doses had been prepared, usually at the end of the work day, but before the oncology pharmacy was cleaned. Several months later, sampling in the same 6 areas was repeated following routine cleaning of the oncology pharmacy and cleaning of the biosafety cabinet with Surface Safe solution (Hospira, Lake Forest, Illinois). At this time, sampling was also performed in 7 areas in the main pharmacy, which acted as a control. Surface Safe is a 2-step applicator kit used to inactivate cytotoxic agents on chemotherapy work surfaces. The first towelette, which contains a $2 \%$ sodium hypochlorite soap solution, neutralizes any cytotoxic agents. The second towelette, which contains $1 \%$ sodium thiosulfate benzyl alcohol, is used to neutralize the sodium hypochlorite.

Sampling locations were selected on the basis of published reports showing the areas with highest yield in health care settings, suggestions accompanying the sampling kit, and the researchers' own assessments as to the locations most likely to be contaminated. The areas sampled in the oncology pharmacy were the outside window of the biosafety cabinet, the work surface of the cabinet, the floor in front of the cabinet, the back wall of the cabinet, the chemotherapy storage drawer, and the pharmacist's checking counter. The areas sampled in the main pharmacy were the counter used to receive drugs from suppliers, the counter used to dispense nonchemotherapy drugs, the room where nonchemotherapy drugs were reconstituted, 2 plastic boxes used to store packaged drugs, and the wall and ceiling of a pharmacist's office.

Surface wipe samples were stored at $-70^{\circ} \mathrm{C}$ in a freezer in the main pharmacy (a different freezer from the one used to store urine samples). The before-cleaning samples from the oncology pharmacy were sent for analysis to the Exposure Control toxicology laboratory in the Netherlands (transported on dry ice at $-80^{\circ} \mathrm{C}$ ). The after-cleaning samples from the oncology pharmacy were sent to the Exposure Control toxicology laboratory in the Netherlands for cyclophosphamide testing and also to the INSPQ for cyclophosphamide, methotrexate, and ifosfamide testing. The samples from the main pharmacy were sent only to the INSPQ laboratory for cyclophosphamide, methotrexate, and ifosfamide testing. 
Surface wipe samples from all locations were collected by a single pharmacist (G.G.), following the standardized instructions accompanying the kit. Different kits were used depending on the laboratory to which the samples were being sent. For samples sent to the Exposure Control laboratory, the Cyto Wipe Kit (supplied by the laboratory) was used. This kit contained $17 \mathrm{~mL}$ of sodium hydroxide solution, 2 tissues, and a container. The sodium hydroxide solution was dripped over a premarked $0.5-\mathrm{m}^{2}$ surface; the first tissue was then used to spread the solution over the area and the second was used to wipe it to dryness. Both tissues were then placed in the container provided and stored at $-20^{\circ} \mathrm{C}$ in a freezer dedicated to this study.

For samples sent to INSPQ, kits supplied by the INSPQ were used. Each kit contained a damp WypAll X-60 tissue (Kimberly Clarke Professional) placed in a 50-mL polypropylene tube and one pair of nitrile gloves. In accordance with instructions accompanying the kit, the tissue was folded in 2, and a premarked $0.6-\mathrm{m}^{2}$ surface was fully wiped first with one side of the tissue and then with the other side. The tissue was then returned to the tube and stored in a refrigerator at $4^{\circ} \mathrm{C}$ until shipment to the INSPQ.

An unused wipe sample was also sent to the INSPQ laboratory, at the laboratory's request, for testing. This sample served as a control. However, the laboratory was not aware which sample was the control. No unused wipe samples were sent to the Exposure Control laboratory for analysis, as no such request was made by that laboratory.

For surface wipes sent to the Exposure Control laboratory, samples were extracted using the procedure described by Sessink and others ${ }^{26,41}$ and were analyzed for cyclophosphamide content by gas chromatography in tandem with mass spectroscopy mass spectroscopy (GC-MS-MS) on a GC-MS-MS system comparable to the previously used GC-MS system. ${ }^{40}$ For surface wipes sent to the INSPQ laboratory, samples were extracted using a procedure validated at the INSPQ laboratory and inspired by Larson and others. ${ }^{42}$ Cyclophosphamide, methotrexate, and ifosfamide were measured with UPLC-MS-MS technology using an Acquity ultra-performance liquid chromatograph with a Quattro Premier XE tandem mass spectrometer (both Waters, Milford, Massachusetts).

\section{RESULTS}

\section{Biological Exposure}

The participants in this study were 7 oncology pharmacy personnel and 5 non-oncology pharmacy personnel (controls). On original testing, all participants in both groups tested positive for urinary cyclophosphamide, with a higher mean concentration of cyclophosphamide in the urine of controls (Figure 1). For most individuals, multiple urine samples tested positive (Appendix 1, available at www.cjhp-online.ca/index.php/cjhp/issue/view/

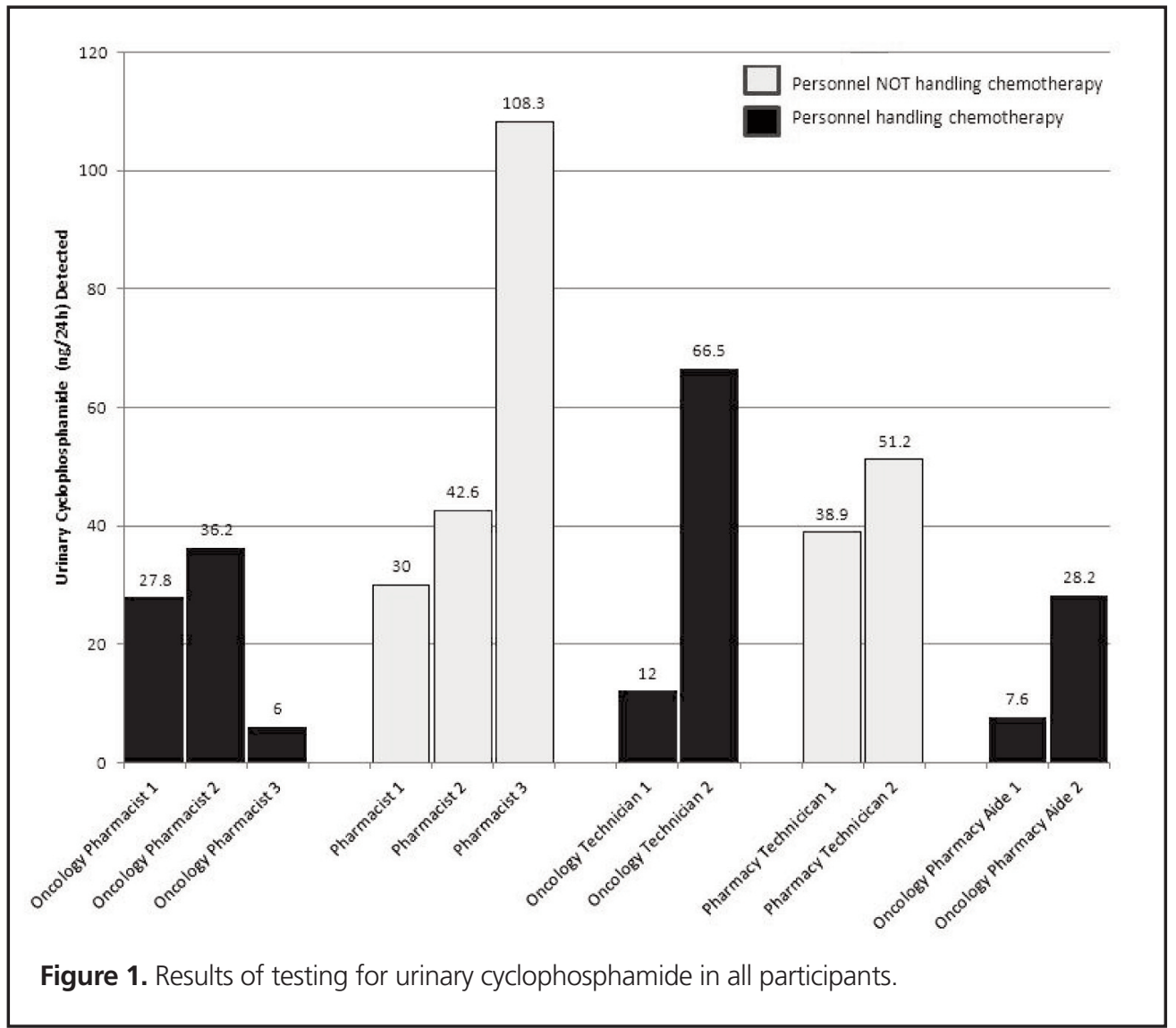




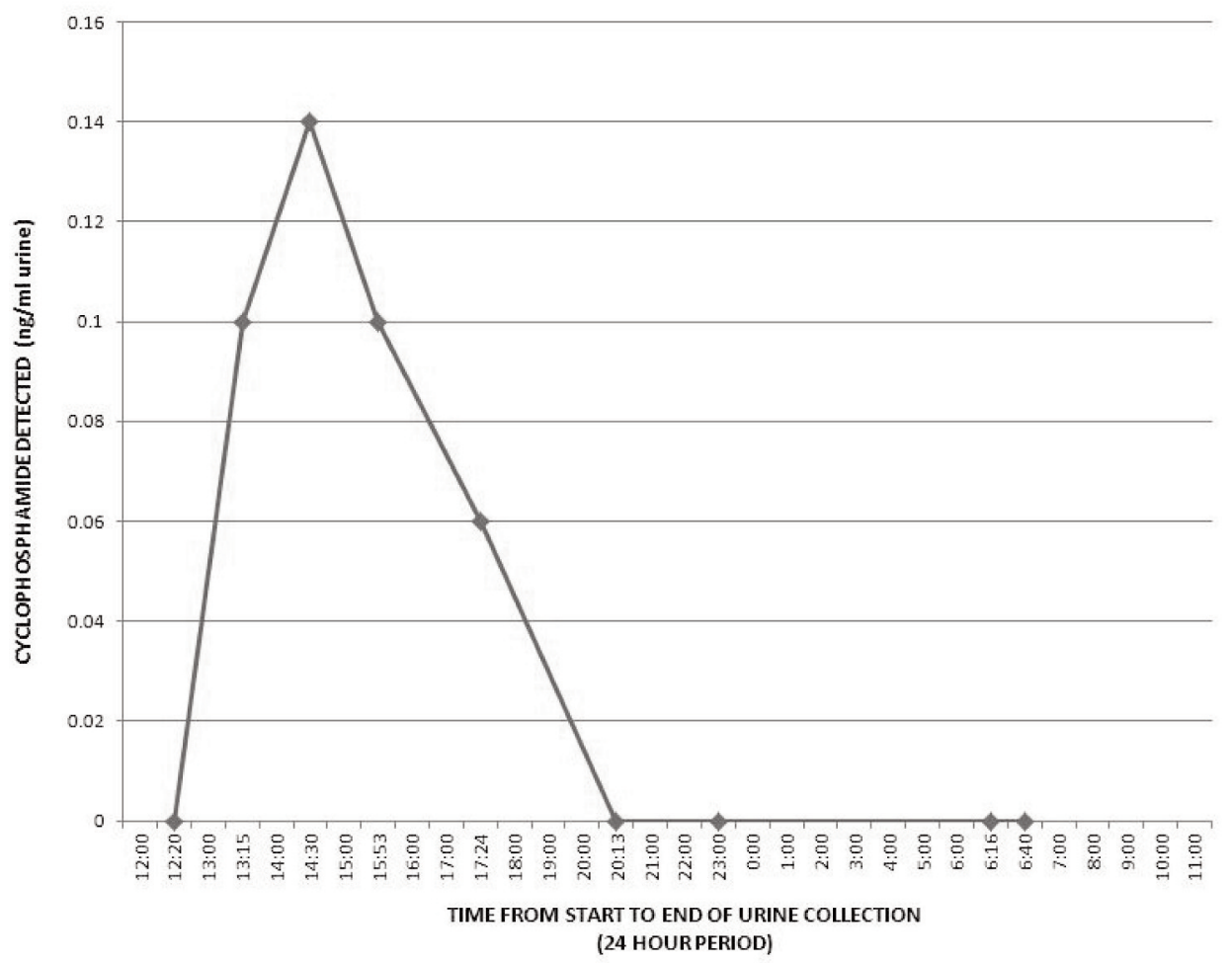

Figure 2. Results of repeat testing for urinary cyclophosphamide in the single control participant who tested positive at that time. The time of the participant's exposure to the oncology clinic on the day of testing was 1130.

108/showToc). Review of the institution's process revealed that all of the controls had been trained to use the urine-collection kit in the oncology pharmacy on the day that urine samples were collected. Therefore, they had all potentially been exposed to a contaminated environment. Moreover, the urine-collection kits had been stored in the oncology pharmacy before the study began and were therefore at risk of having been contaminated.

Therefore, urine testing of controls was repeated. The urinecollection kits for repeat testing were not stored in the oncology pharmacy. On the day of repeat testing, participants were specifically asked to avoid any areas that were potentially contaminated with chemotherapy, such as the oncology ward, the oncology clinic, and the oncology pharmacy. All were compliant with this instruction, except for one control who visited the oncology pharmacy briefly during the 24-h study period; this person tested positive for urinary cyclophosphamide on repeat testing. More specifically, 4 of the 8 urine samples provided by this participant were positive (Figure 2), and all 4 of these positive urine samples were obtained after exposure to the oncology pharmacy.

\section{Before-Cleaning Wipe Samples}

The before-cleaning surface wipes from the oncology pharmacy, analyzed at the Exposure Control laboratory, showed cyclophosphamide contamination in 3 of 5 areas tested and methotrexate contamination in 1 of 6 areas tested (Table 2).

\section{After-Cleaning Wipe Samples}

Wipe samples collected after cleaning of the oncology pharmacy and the biosafety cabinet were sent to Exposure Control and INSPQ as described above. Analysis at the Exposure Control laboratory showed contamination with cyclophosphamide in the same 3 areas as previously reported, and analysis at INSPQ revealed cyclophosphamide contamination in 2 of 5 areas tested, including the same areas that tested positive by the Exposure Control laboratory (Table 2). Surface wipes sent only to the INSPQ laboratory also revealed methotrexate contamination of 3 of 6 areas tested (including the storage drawer, which also tested positive on before-cleaning sampling) and ifosfamide contamination of 2 of 5 areas tested (Table 2). Surface wipes from the main pharmacy (control), sent only to the INSPQ laboratory for cyclophosphamide, methotrexate, and ifosfamide testing, were all negative (Table 3). The unused wipe sent to the INSPQ laboratory as a control tested negative for cyclophosphamide, methotrexate, and ifosfamide.

\section{DISCUSSION}

This study showed that environmental contamination with all 3 chemotherapy drugs tested was widespread in the oncology pharmacy (where chemotherapy doses were stored and prepared) but was absent in the main pharmacy (where chemotherapy 
This single copy is for your personal, non-commercial use only.

For permission to reprint multiple copies or to order presentation-ready copies for distribution, contact CJHP at cjhpedit@cshp.ca

Table 2. Results of Surface Wipe Testing for 3 Chemotherapy Agents in the Oncology Pharmacy before and after Cleaning

\begin{tabular}{|c|c|c|c|c|c|c|}
\hline \multirow[b]{2}{*}{ Surface } & \multicolumn{2}{|c|}{$\begin{array}{c}\text { Drug; Concentration } \\
\text { before Cleaning }\left(\mathrm{ng} / \mathrm{cm}^{2}\right)\end{array}$} & \multicolumn{4}{|c|}{$\begin{array}{l}\text { Drug; Concentration after Cleaning } \\
\left(\mathrm{ng} / \mathrm{cm}^{2}\right)\end{array}$} \\
\hline & $\begin{array}{c}\text { MTX } \\
\text { (EC lab) }\end{array}$ & $\begin{array}{c}\text { CPM } \\
\text { (EC lab) }\end{array}$ & $\begin{array}{c}\text { MTX } \\
\text { (INSPQ lab) }\end{array}$ & $\begin{array}{c}\text { CPM } \\
\text { (EC lab) }\end{array}$ & $\begin{array}{c}\text { CPM } \\
\text { (INSPQ lab) }\end{array}$ & $\begin{array}{c}\text { IFM } \\
\text { (INSPQ lab) }\end{array}$ \\
\hline $\begin{array}{l}\text { Outside window of } \\
\text { biosafety cabinet }\end{array}$ & ND & 0.08 & 0.25 & 0.05 & 0.0083 & 0.0090 \\
\hline $\begin{array}{l}\text { Work surface of } \\
\text { biosafety cabinet }\end{array}$ & ND & ND & 1.0 & ND & ND & ND \\
\hline $\begin{array}{l}\text { Floor in front of biosafety } \\
\text { cabinet }\end{array}$ & ND & 0.06 & ND & 0.04 & 0.0120 & 0.0035 \\
\hline $\begin{array}{l}\text { Back wall of biosafety } \\
\text { cabinet }\end{array}$ & ND & 0.07 & ND & 0.20 & ND & ND \\
\hline Storage drawer & 0.66 & NT & 1.4 & ND & NT & NT \\
\hline $\begin{array}{l}\text { Pharmacist's checking } \\
\text { counter }\end{array}$ & ND & ND & NT & NT & NT & NT \\
\hline Blank control & NT & NT & ND & NT & ND & ND \\
\hline
\end{tabular}

CPM = cyclophosphamide, EC lab = Exposure Control laboratory (The Netherlands), IFM = ifosfamide, INSPQ lab = toxicology laboratory of the Institut national de santé publique du Québec, MTX = methotrexate, ND = not detected, NT = not tested.

Table 3. Results of Surface Wipe Testing for 3 Chemotherapy Agents in the Main (Control) Pharmacy

\begin{tabular}{|c|c|c|c|}
\hline \multirow[b]{2}{*}{ Surface } & \multicolumn{3}{|c|}{ Drug; Test Result from INSPQ Lab } \\
\hline & Cyclophosphamide & Methotrexate & Ifosfamide \\
\hline $\begin{array}{l}\text { Counter used to receive drugs } \\
\text { from suppliers }\end{array}$ & ND & ND & ND \\
\hline $\begin{array}{l}\text { Counter used to dispense } \\
\text { nonchemotherapy drugs }\end{array}$ & ND & ND & ND \\
\hline $\begin{array}{l}\text { Room where nonchemotherapy } \\
\text { drugs were reconstituted }\end{array}$ & ND & ND & ND \\
\hline \multicolumn{4}{|l|}{$\begin{array}{l}\text { Plastic boxes used to store } \\
\text { packaged drugs }\end{array}$} \\
\hline Box 1 & ND & ND & ND \\
\hline Box 2 & ND & ND & ND \\
\hline \multicolumn{4}{|l|}{ Pharmacist's office } \\
\hline Wall & ND & ND & ND \\
\hline Ceiling & ND & ND & ND \\
\hline
\end{tabular}

drugs were received and stored only briefly). In the oncology pharmacy, contamination occurred mainly around the biosafety cabinet where chemotherapy drugs were reconstituted. Several other studies have consistently shown contamination of such equipment. ${ }^{30,34,43,44}$ This result is not surprising, given that this location is where all chemotherapy drugs, in their concentrated form, are reconstituted. The chemotherapy storage drawers in the oncology pharmacy were also contaminated. Other studies have shown that the outside of chemotherapy vials may be contaminated, ${ }^{26}$ and this is the likely source of contamination of the storage drawers in the current study. However, no contamination was detected in the main pharmacy, possibly because the vials were received in boxes that were not opened there, and the boxes were immediately stored in sealed containers. Therefore, the vials would not have come into direct contact with any surface in the main pharmacy.
In the oncology pharmacy, the biosafety cabinet was wiped with alcohol and water, as per routine practice, for the original testing and with a specially formulated cleaning solution for the after-cleaning samples. The same areas in and around the biosafety cabinet tested positive, at similar levels, before and after cleaning with the specially formulated solution. Other studies have had similar results. ${ }^{36,44}$ Although it would have been preferable to have all surface wipes analyzed by the same laboratory, there was good correlation between results from the 2 laboratories for surface wipes from the same areas at the same time point.

Environmental exposure appears to result in biological exposure, as demonstrated by the positive results of urine testing for all participants in the initial phase of the study. Control participants, whose only known exposure to cyclophosphamide in the week before study participation was their visit to the oncology pharmacy on the day of study participation, all tested 
positive for urinary cyclophosphamide at higher mean and median concentrations than the oncology pharmacy personnel. However, on repeat testing, none of the controls who refrained from visiting the oncology pharmacy on the day of study participation tested positive. The one control participant who did visit the oncology pharmacy on the repeat study day tested positive, and urinary cyclophosphamide was detected only after the participant's exposure to the oncology pharmacy. These results suggest that the contaminated environment in the oncology pharmacy was the likely source of exposure. Whether biological exposure occurred through skin, inhalation, ingestion, or a combination of these routes is unclear. If it is postulated that the only source of exposure for controls at the time of original urine testing was the contaminated oncology pharmacy, there would seem to be no association between the duration of environmental exposure and the degree of biological exposure. The controls had a much shorter duration of exposure to the contaminated environment than the oncology personnel but had greater biological exposure to cyclophosphamide. One possible explanation is that although the oncology personnel were in the contaminated environment for longer periods than the controls, they may have been more vigilant about using protective measures (such as handwashing before eating). Alternatively, it is possible that controls were exposed through some other source. For example, Yoshida and others ${ }^{44}$ analyzed wipe samples from the airconditioning filters of 2 hospitals for cyclophosphamide and obtained positive results. On this basis, it could be postulated that central air heating systems, which are connected to various parts of a hospital, may be similarly affected. However, exposure from a source other than the oncology pharmacy is unlikely, as the controls tested negative on repeat testing, when they were not exposed to the oncology pharmacy.

This study differed from most other similar studies in that it included control groups for both environmental and biological exposure. To the authors' knowledge, no other studies have used concurrent control areas when testing for environmental contamination, and only one other study used a control group when measuring biological exposure to antineoplastic drugs among pharmacy personnel. ${ }^{30}$ In that study, 3 of 17 pharmacy personnel handling chemotherapy drugs tested positive, and all 14 pharmacy personnel not handling chemotherapy drugs tested negative. However, the method and duration of urine sample collection and the laboratory where samples were analyzed differed between that study and the current one, which makes comparisons difficult. The current study analyzed urine samples from each participant collected over a 24-h period, with each void being analyzed individually. In contrast, Connor and others ${ }^{30}$ analyzed urine samples collected from each participant over an 8-h period, with pooling of urine voids from each 4-h period and testing of 2 samples per person. Pooling may have diluted positive samples, with fewer samples reaching the lower limit of detection for cyclophosphamide. The shorter collection period (the last $4 \mathrm{~h}$ of the work shift and the first $4 \mathrm{~h}$ after the end of the work shift) would have missed any positive samples that occurred beyond $8 \mathrm{~h}$. In the current study, several participants had positive samples more than $8 \mathrm{~h}$ after collection started.

The steps required to correct the problem of occupational exposure to chemotherapy must go beyond measures to enhance the protection of health care workers preparing chemotherapy doses. They should also include reducing environmental contamination to protect everyone who is exposed to the hospital environment. However, many Canadian health care institutions do not meet recommended safety standards. At the time this study was undertaken, the oncology pharmacy in the study institution did not meet standards for a Class 10000 clean room and did not have sufficient general exhaust ventilation; these deficiencies have now been corrected. Moreover, a closed-system device has been installed to reduce aerosolization of chemotherapy agents, and more effective cleaning methods are being trialled. It is hoped that these additional measures will reduce environmental contamination at the study hospital, which should reduce biological exposure. Given that cyclophosphamide is only one of several dozen chemotherapy drugs that health care workers routinely prepare and administer in hospitals, implementing measures to reduce both environmental contamination and biological exposure to all chemotherapy agents should be a priority at all health care institutions. Such efforts will help to ensure the safety of health care workers and others exposed to the hospital environment.

\section{References}

1. IARC monographs on the evaluation of carcinogenic risks to humans. Lyon (France): International Agency for Research on Cancer; [updated $2014 \mathrm{Oct}$ 23; cited 2014 Jan 28]. Available from: http://monographs.iarc.fr/ENG/ Classification/index.php

2. Sorsa M, Anderson D. Monitoring of occupational exposure to cytostatic anticancer agents. Mutat Res. 1996;355(1-2):253-61.

3. Baker ES, Connor TH. Monitoring occupational exposure to cancer chemotherapy drugs. Am J Health Syst Pharm. 1996;53(22):2713-23.

4. Bos RP, Sessink PJM. Biomonitoring of occupational exposure to cytostatic anticancer drugs. Rev Environ Health. 1997;12(1):43-58.

5. Hewitt JB. Health effects of occupational exposure to antineoplastic drugs: an integrative research approach. Toronto $(\mathrm{ON})$ : Ministry of Labour, Industrial Disease Panel; 1997.

6. Harrison BR. Risks of handling cytotoxic drugs. In: Perry MC, editor. The chemotherapy source book. 3rd ed. Philadelphia (PA): Lippincott, Williams and Wilkins; 2001. p. 566-82.

7. Selevan SG, Lindbohm ML, Hornung RW, Hemminki K. A study of occupational exposure to antineoplastic drugs and fetal loss in nurses. $N$ Engl J Med. 1985;313(19):1173-8.

8. Hemminki K, Kyyrönen P, Lindbohm ML. Spontaneous abortions and malformations in the offspring of nurses exposed to anaesthetic gases, cytostatic drugs, and other potential hazards in hospitals, based on registered information of outcome. J Epidemiol Community Health. 1985;39(2):141-7.

9. Peelen S, Roeleveld N, Heederik D, Krombout H, de Kort W. Reproductietoxische effecten bij ziekenhuispersonel [Toxic effects on reproduction in hospital personnel]. Amsterdam (Netherlands): Elsevier; 1999.

10. Valanis B, Vollmer WM, Steele P. Occupational exposure to antineoplastic agents: self-reported miscarriages and stillbirths among nurses and pharmacists. J Occup Environ Med. 1999;41(8):632-8.

11. Hirst M, Tse S, Mills DG, Levin L, White DF. Occupational exposure to cyclophosphamide. Lancet. 1984;1(8370):186-8.

12. Falck K, Gröhn P, Sorsa M, Vainio H, Heinonen E, Holsti LR. Mutagenicity in urine of nurses handling cytostatic drugs. Lancet. 1979;1(8128):1250-1. 
13. Fransman W, Peelen S, Hilhorst S, Roeleveld N, Heederik D, Kromhout H. A pooled analysis to study trends in exposure to antineoplastic drugs among nurses. Ann Occup Hyg. 2007;51(3):231-9.

14. Rekhadevi PV, Sailaja M, Chandrasekhar M, Mahboob M, Rahman MF, Grover P. Genotoxicity assessment in oncology nurses handling antineoplastic drugs. Mutagenesis. 2007;22(6):395-401.

15. Cavallo D, Ursini CL, Perniconi B, Francesco AD, Giglio M, Rubino FM, et al. Evaluation of genototoxic effects induced by exposure to antieoplastic drugs in lymphocytes and exfoliated buccal cells of oncology nurses and pharmacy employees. Mutat Res. 2005;587(1-2):45-51.

16. Turci R, Sottani C, Ronchi A, Minoia C. Biological monitoring of hospital personnel occupationally exposed to antineoplastic agents. Toxicol Lett. 2002;134(1-3):57-64

17. Ensslin AS, Stoll Y, Pethran A, Pfaller A, Römmelt H, Fruhmann G. Biological monitoring of cyclophosphamide and ifosfamide in urine of hospital personnel occupationally exposed to cytostatic drugs. Occup Environ Med. 1994;51(4):229-33.

18. Burgaz S, Karahalil B, Canhi Z, Terzioglu F, Ançel G, Anzion RB, et al. Assessment of genotoxic damage in nurses occupationally exposed to antineoplastics by the analysis of chromosomal aberrations. Hum Exp Toxicol. 2002;21(3):129-35.

19. Sessink PJM, Cerná M, Rössner P, Pastorková A, Bavarová H, Franková K, et al. Urinary cyclophosphamide excretion and chromosomal aberrations in peripheral blood lymphocytes after occupational exposure to antineoplastic agents. Mutat Res. 1994;309(2):193-9.

20. Burgaz S, Karahalil B, Bayrak P, Taşkin L, Yavuzaslan F, Bökesoy I, et al. Urinary cyclophosphamide excretion and micronuclei frequencies in peripheral lymphocytes and in exfoliated buccal epithelial cells of nurses handling antineoplastics. Mutat Res. 1999;439(1):97-104.

21. Ursini CL, Cavallo D, Colombi A, Giglio M, Marinaccio A, Iavicoli S. Evaluation of early DNA damage in healthcare workers handling antineoplastic drugs. Int Arch Occup Environ Health. 2006;80(2):134-40.

22. Ziegler E, Mason HJ, Baxter PJ. Occupational exposure to cytotoxic drugs in two UK oncology wards. Occup Environ Med. 2002;59(9):608-12.

23. Fransman W, Vermeulen R, Kromhout H. Occupational dermal exposure to cyclophosphamide in Dutch hospitals: a pilot study. Ann Occup Hyg. 2004;48(3):237-44.

24. Fransman W, Vermeulen R, Kromhout H. Dermal exposure to cyclophosphamide in hospitals during preparation, nursing and cleaning activities. Int Arch Occup Environ Health. 2005;78(5):403-12.

25. Kromhout H, Hoek F, Uitterhoeve R, Huijbers R, Overmars RF, Anzion $\mathrm{R}$, et al. Postulating a dermal pathway for exposure to anti-neoplastic drugs among hospital workers. Applying a conceptual model to the results of three workplace surveys. Ann Occup Hyg. 2000;44(7):551-60.

26. Sessink PI, Boer KA, Scheefhals AP, Anzion RB, Bos RP. Occupational exposure to antineoplastic agents at several departments in a hospital: environmental contamination and excretion of cyclophosphamide and ifosfamide in urine of exposed workers. Int Arch Occup Environ Health. 1992;64(2):105-12

27. Wick C, Slawson MH, Jorgensen JA, Tyler LS. Using a closed-system protective device to reduce personnel exposure to antineoplastic agents. Am J Health Syst Pharm. 2003;60(22):2314-20.

28. Pethran A, Schierl R, Hauff K, Grimm CH, Boos KS, Nowak D. Uptake of antineoplastic agents in pharmacy and hospital personnel. Part 1: monitoring of urinary concentrations. Int Arch Occup Environ Health. 2002;76(1):5-10.

29. Connor TH, Anderson RW, Sessink PJ, Broadfield L, Power LA. Surface contamination with antineoplastic agents in six cancer treatment centers in Canada and the United States. Am J Health Syst Pharm. 1999;56(14): 1427-32.

30. Connor TH, DeBord DG, Pretty JR, Oliver MS, Roth TS, Lees PS, et al. Evaluation of antineoplastic drug exposure of health care workers at three university-based US cancer centers. J Occup Environ Med. 2010; 52(10):1019-27.

31. Nyman H, Jorgenson J, Slawson M. Workplace contamination with antineoplastic agents in a new cancer hospital using a closed-system drug transfer device. Hosp Pharm. 2007;42(3):219-25.

32. McDevitt JJ, Lees PS, McDiarmid MA. Exposure of hospital pharmacists and nurses to antineoplastic agents. J Occup Med. 1993;35(1):57-60.

33. Connor TH, Anderson RW, Sessink PJ, Spivey SM. Effectiveness of a closed-system device in containing surface contamination with cyclophosphamide and ifosfamide in an i.v. admixture area. Am J Health Syst Pharm. 2002;59(1):68-72.

34. Sessink PJ, Connor TH, Jorgenson JA, Tyler TG. Reduction in surface contamination with antineoplastic drugs in 22 hospital pharmacies in the
US following implementation of a closed-system drug transfer device. $J$ Oncol Pharm Pract. 2010;17(1):39-48.

35. Harrison BR, Peters BG, Bing MR. Comparison of surface contamination with cyclophosphamide and fluorouracil using a closed-system drug transfer device versus standard preparation techniques. Am J Health Syst Pharm. 2006;63(18):1736-44

36. Chu WC, Hon CY, Danyluk Q, Chua PP, Astrakianakis G. Pilot assessment of the antineoplastic drug contamination levels in British Columbian hospitals pre- and post-cleaning. J Oncol Pharm Pract. 2012;18(1):46-51.

37. Touzin K, Bussières JF, Langlois E, Lefebvre M. Evaluation of surface contamination in a hospital hematology-oncology pharmacy. J Oncol Pharm Pract. 2009;15(1):53-61.

38. General chapter $<797>$ : pharmaceutical compounding - sterile preparations (revised). In: USP 27-NF 22 [The United States pharmacopeia, 27th revision, and The national formulary, 22nd ed]. Rockville (MD): The United States Pharmacopeial Convention; 2008.

39. Taketoma CK, Hodding JH, Kraus DM. Pediatric dosage handbook. 14th edition. Hudson $(\mathrm{OH})$ : Lexicomp; 2007.

40. Sessink PJM, Scoltes MM, Anzion RB, Bos RP. Determination of cyclophosphamide in urine by gas chromatography-mass spectrometry. $J$ Chromatogr. 1993;616(2):333-7.

41. Sessink PJM, Anzion RB, Van den Broek PH, Bos RP. Detection of contamination with antineoplastic agents in a hospital pharmacy department. Pharm Weekbl Sci. 1992;14(1):16-22.

42. Larson RR, Khazaeli MB, Dillon HK. Monitoring method for surface contamination caused by selected antineoplastic agents. Am J Health Syst Pharm. 2002;59(3):270-7.

43. Sugiura S, Nakanishi H, Asano M, Hashida T, Tanimura M, Hama T, et al Multicenter study for environmental and biological monitoring of occupational exposure to cyclophosphamide in Japan. J Oncol Pharm Pract. 2010;17(1):20-8

44. Yoshida J, Koda S, Nishida S, Yoshida T, Miyajima K, Kumagai S. Association between occupational exposure levels of antineoplastic drugs and work environment in five hospitals in Japan. J Oncol Pharm Pract. 2010;17(1):29-38.

Raveena Ramphal, MBChB, FRACP, MPH, is a Pediatric Hematologist/ Oncologist at the Children's Hospital of Eastern Ontario; an Associate Professor with the Department of Pediatrics, University of Ottawa; and a Clinical Investigator with the Children's Hospital of Eastern Ontario Research Institute, Ottawa, Ontario.

Tejinder Bains, BSC(Pharm), ACPR, is a Pharmacist with the Children's Hospital of Eastern Ontario, Ottawa, Ontario.

Geneviève Goulet, BPharm, PharmD, RPh, is a Pharmacist with the Children's Hospital of Eastern Ontario, Ottawa, Ontario.

Régis Vaillancourt, OMM, CD, BPharm, PharmD, FCSHP, is the Director of Pharmacy with the Children's Hospital of Eastern Ontario, Ottawa, Ontario.

Competing interests: Raveena Ramphal and Régis Vaillancourt have received unrestricted grants from Phaseal Co for an unrelated study. No other competing interests were declared.

\section{Address correspondence to:}

Dr Raveena Ramphal

Division of Hematology/Oncology

Children's Hospital of Eastern Ontario

401 Smyth Road

Ottawa ON K1H 8L1

e-mail: rramphal@cheo.on.ca

Acknowledgements: The authors thank the study participants who volunteered for this study. They also thank Dr Paul Sessink, Expsoure Control B.V., Wageningen, The Netherlands, and personnel of the toxicology laboratory of the Institut national de santé publique du Québec, Quebec, for assistance with sample analysis.

Funding: Funding for the study was obtained from the Department of Pharmacy, Children's Hospital of Eastern Ontario. 